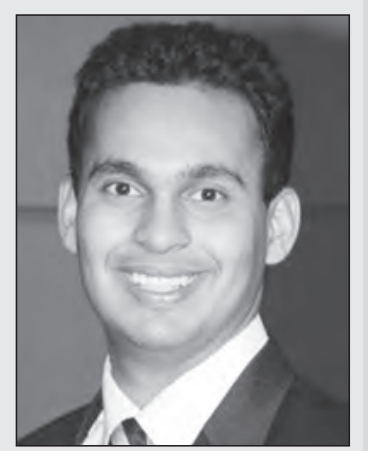

Vikram Chand*

\title{
The Guiding Principle and the Principal Purpose Test
}

\section{The background to the Guiding Principle}

The 2003 OECD Commentary on Article 1 raised two questions with respect to improper use of tax treaties ${ }^{1}$. The first question was whether tax treaty benefits must be granted when transactions entered into by taxpayer's abuse the provisions of tax treaties and the second question is whether domestic anti abuse measures, that are intended to prevent abuse, conflict with tax treaties ${ }^{2}$.

In relation to the second question, the Commentary makes a reference to Para 22.1 and provides that as a general rule and having regard to para 9.5, there will be no conflict ${ }^{3}$.

With respect to the first question, Para 9.2 provides that several States consider that taxes are levied through domestic law as restricted by tax treaties. Thus, for these States an abuse of tax treaty can be considered as an abuse of domestic law. Accordingly, for these States the issue then becomes whether the provisions of tax treaties may prevent the application of the domestic anti-abuse provisions. In this regard the Commentary, by referring to Para 22.1, provides that domestic anti avoidance rules, in general, do not conflict with tax treaties ${ }^{4}$.

Also, with respect to the first question, Para 9.3 provides that other States tackle treaty abuse by a proper construction of tax treaties. This construction results from the object and purpose of tax treaties (which includes prevention of tax avoidance) ${ }^{5}$ as well as the obligation to interpret them in good faith pursuant

* Vikram Chand is the Academic Coordinator, Masters of Advanced Studies in International Taxation, at the University of Lausanne, Switzerland. The author can be contacted at vikram.chand@unil.ch.

International Taxation $\square$ Vol. 12 - June 2015 - 34 
to Article 31 of the Vienna Convention of the Law on Treaties (VCLT) ${ }^{6}$.

The Commentary then concludes in Para 9.4 that, irrespective of the approach followed by the first or second group of States, the benefit of tax treaties should not be granted to arrangements that constitute an abuse ${ }^{7}$.

The Commentary does not elaborate on what is an abusive arrangement. Nevertheless, in Para 9.5 the Commentary introduces a guiding principle that provides "that the benefits of a double taxation convention should not be available where a main purpose (subjective element) for entering into certain transactions or arrangements was to secure a more favourable tax position and obtaining that more favourable treatment in these circumstances would be contrary to the object and purpose of the relevant provisions (objective element)" ${ }^{\prime \prime}$.

\section{The background to the Principal Purpose Test}

In February 2013, the OECD released its report on Addressing Base Erosion and Profit Shifting (BEPS) ${ }^{9}$. Subsequently, in July 2013, the OECD released its 15-point Action Plan to address $\mathrm{BEPS}^{10}$. In this plan, treaty abuse, in particular, treaty shopping was considered to be one of the most important sources of BEPS concerns. Accordingly, Action 6 was dedicated to prevent treaty abuse. Thereafter, in March 2014, the OECD released its discussion draft on Action $6^{11}$. Following a two-day public consultation in April - the OECD released its report on treaty abuse (2014 TTA report) as part of its seven deliverables due in September 2014 ${ }^{12}$. It is clearly indicated that the recommendations made in the report are at a draft stage and further refinement is necessary ${ }^{13}$. Essentially, the report suggests treaty anti abuse rules and provides clarificatory commentary for domestic anti abuse rules.

With respect to treaty measures, the 2014 TTA Report suggests a three-prong approach to counter treaty shopping. Firstly, the title and preamble of tax treaties is modified to clearly include a statement that when States enter into tax treaties their intention is not to create opportunity for tax avoidance or evasion including treaty-shopping arrangements. Secondly, a treaty targeted anti avoidance rule (TAAR) in line with the US style limitation of benefits (LOB) clause is proposed to be included in tax treaties. Thirdly, a treaty general anti avoidance rule (GAAR) in the form of a principal purpose test (PPT), which resembles the guiding principle, is proposed.

The PPT clause provides that: "Notwithstanding the other provisions of this Convention, a benefit under this Convention shall not be granted in respect of an item of income or capital if it is reasonable to conclude, having regard to all relevant facts and circumstances, that obtaining that benefit was one of the principal purposes (subjective element) of any arrangement or transaction that resulted directly or indirectly in that benefit, unless it is established that granting that benefit in these circumstances would be in accordance with the object and purpose of the relevant provisions of this Convention" (objective element). ${ }^{14}$ Other Treaty TAAR's are also proposed.

With respect to the interaction of domestic anti abuse measures with tax treaties, it is stated that States apply domestic Anti-avoidance Measures to avoid domestic BEPS concerns. In many situations, taxpayers argue that such measures conflict with tax treaties as treaties rank at a higher pedestal than domestic law. The report provides that a conflict does not arise between domestic anti abuse rules and tax treaties by referring to the comments made in the 2003/2014 Commentary to Article 1 in Paras 22.1 and $9.5^{15}$. The report also provides that the conclusions already reflected in the Commentary on Article 1 on the interaction between treaties and domestic anti abuse measures remain applicable even if tax treaties do not incorporate the PPT rule ${ }^{16}$. Thereafter, "clarificatory" draft commentary is provided which recognizes that domestic TAAR's, 
statutory GAAR's and judicial doctrines can be used to counter treaty abuse.

With respect to domestic TAAR's, it is provided that if a conflict arises between a domestic TAAR and tax treaty the latter will prevail pursuant to Article 26 VCLT $^{17}$. However, such conflicts can be avoided if: firstly, the treaty contains an express provision which allows the application of a domestic TAAR ${ }^{18}$; secondly, if the domestic TAAR gives a meaning to a term and that term in incorporated in a tax treaty because a reference is made to the domestic law to understand the treaty meaning of that term ${ }^{19}$; thirdly, it is stated that a conflict does not arise if treaty benefits are denied both under the domestic TAAR and the guiding principle or PPT rule ${ }^{20}$; lastly, a conflict does not arise if the benefits of tax treaties are denied under both domestic judicial doctrines and principles applicable to treaty interpretation coupled with domestic TAAR's ${ }^{21}$.

With respect to the interaction of domestic statutory GAAR's with tax treaties, the draft commentary states that a conflict will not arise if: the treaty includes a specific provision for its application; or if the domestic statutory GAAR gives a meaning to a term and that term in incorporated in a tax treaty because a reference is made to the domestic law to understand the treaty meaning of that term; or if the domestic rule is in conformity with the guiding principle/PPT rule $^{22}$.

With respect to judicial doctrines (substance over form, economic substance, sham, business purpose, step transaction, abuse of law and fraus legis), it is stated that these interpretational principles do not conflict with tax treaties even though treaties have to be interpreted in light of the VCLT. The relevance of the guiding principle/PPT rule towards this approach is not discussed.

The report also clarifies that CFC rules do not conflict with treaty provisions. This position is justified by the introduction of a US type Saving clause ${ }^{23}$. By referring to the Saving clause it is also clarified that exit taxes do not conflict with tax treaties ${ }^{24}$.

\section{The guiding principle and PPT rule - Selected issues}

\section{Preliminary remarks}

The 2003/2014 OECD Commentary suggests that irrespective of the approach adopted to counter treaty abuse i.e. either through domestic anti avoidance rules $^{25}$ or the interpretation approach, such measures should be applied taking into consideration the guiding principles that essentially is a treaty GAAR. Likewise, the 2014 TTA report provides that States can counteract improper use of tax treaties (treaty shopping and rule shopping) through the PPT rule. It is also stated at several occasions that domestic anti avoidance rules have to be applied in conformity with the guiding principle or the PPT rule. Thus, the guiding principle/the PPT rule are of paramount importance and their elements will be discussed hereafter in this contribution.

\section{The PPT rule and guiding principle vs Treaty} TAAR's

The question arises as to how do these treaty anti abuse rules (GAAR and TAAR's) interact with each other? In this regard, it should be noted that the 2014 TTA report provides that the PPT rules applies "notwithstanding" the other provisions of this Convention. In the author's opinion, this is an unreasonable conclusion. If one applies the interpretation doctrine of lex specialis derogat legi generali then the treaty TAAR's should prevail over treaty GAAR's when such anti abuse rules apply to similar factual patterns. However, due to the use of the term "notwithstanding" the PPT rules becomes a self-standing provision and thus applies even if the transaction undertaken by the taxpayer passes the tests of the treaty TAAR' $\mathrm{s}^{26}$.

If the treaty does not incorporate the PPT rule but only treaty TAAR's then the question arises as to how these latter rules will interact 
with the OECD's guiding principle. In the author's opinion, the OECD Commentary is not binding and the guiding principle should not be applied, especially, to tax treaties post $2003^{27}$. The text of the treaty should carry more weight than the recommendations made to the OECD Commentary. Thus, if the taxpayer satisfies the treaty TAAR's then the guiding principle should not be used to deny treaty benefits to the taxpayer.

\section{The subjective element}

Treaty benefits will be denied under the guiding principle/the PPT rule if it is proved that that "a main purpose" or "one of the principal purposes" for entering into the transaction/ arrangement (respectively) was to obtain a tax benefit. The OECD uses this terminology as opposed to "the main purpose" test or "the sole purpose" or "the predominant purpose". This implies that, even if an arrangement has many main/principal purposes and to obtain a tax benefit was one of the main/principal purposes, the arrangement undertaken by the taxpayer will satisfy this test ${ }^{28}$. Thus, by providing for "a main purpose" or "one of the principal purposes" test the OECD provides for a low threshold to uphold the abuse of a tax treaty ${ }^{29}$. Accordingly, commentators have criticized this test as transactions with sufficient business purpose or economic substance may come under its scope $^{30}$.

In the author's opinion, these low threshold tests as provided by the OECD should be replaced by "the main purpose" or "the principal purpose" test so that transactions which genuine economic objectives come out of the purview of the guiding principle/PPT rule $^{31}$. This change will also be at par with the trend in the European Union to tackle aggressive tax planning. For instance, the European Court of Justice in the Halifax ${ }^{32}$ judgment specified that tax benefits could be denied if "the essential aim" of the transaction is to obtain tax benefits that are abusive. Similarly, the European Commission in its various initiatives to counter aggressive tax planning recommends the use such similar "the essential purpose" terminology ${ }^{33}$.

\section{The objective element}

The objective element under the guiding principle/PPT rule provides that it needs be checked if the favourable tax position defeats the "object and purpose of the relevant" tax treaty provisions ${ }^{34}$. Tax avoidance structures typically aim to exploit the distributive rules (Art. 6-22) of tax treaties. Accordingly, the object and purpose of the relevant distributive rules needs to be ascertained before it can be established that a taxpayer's transaction is abusive of (defeats) the objective of the relevant distributive rules ${ }^{35}$.

Determining the object and purpose of the distributive rules is not a simple task. Arguably, the object and purpose of the distributive rules is to allocate taxing rights over the various items of income and capital amongst States. However, this objective is not of great help to ascertain whether a particular arrangement defeats the object and purpose of the relevant treaty provisions. This is because under a treaty or rule shopping arrangement or any other form of tax avoidance transaction - a taxpayer formally respects the conditions imposed by the relevant distributive rule but usually acts against the underlying spirit (intentions) of the treaty ${ }^{36}$.

\section{Burden of Proof}

With respect to the guiding principle, the 2003/2014 OECD Commentary does not discuss as to which party is required to demonstrate that these two elements are satisfied. In this respect, the author submits that the tax authorities assume the burden of proof and they have to prove that the impugned transaction undertaken by the taxpayer satisfies both elements ${ }^{37}$.

However this conclusion is different with respect to the PPT rule. Even though the tax authorities will be required to undertake objective analysis facts of the transaction 
they only have to "reasonably" (and not convincingly) conclude that the subject element is satisfied ${ }^{38}$. This threshold seems to be low in comparison to the burden assumed by the taxpayer wherein it is required to "establish" (convincingly) that granting the benefit is in accordance with the object and purpose of the relevant provisions of the tax treaty. Thus the burden of proof is unbalanced ${ }^{39}$.

\section{Outcome of denial of treaty benefits}

Consider a rule-shopping scheme wherein a taxpayer enters into an arrangement to transform taxable dividends (taxable at source under Article 10(2)) to treaty exempt capital gains on shares (exempt from tax at source under Article 13(5)). If the guiding principle/ PPT rule applies to this transaction then treaty benefits (the benefit of exempting from source taxation) shall not be granted. Does this mean that the item of income will be taxable as per the domestic law of the source State (for instance @ 35\%) or can the taxpayer still invoke the provisions of Article 10(2) (for instance @ 15\%) and request for treaty relief?

The OECD's view is that the item of income should then be taxed as per the domestic law of the source State ${ }^{40}$. However, at the moment of writing this contribution, the OECD is considering as to whether the tax authorities should provide some sort of discretionary relief in the same manner as provided by the discretionary relief provision of the LOB clause $?^{41}$ In the author's opinion, treaty benefits under Article 10(2) should be granted to the taxpayer automatically rather than referring to a discretionary relief clause as it could be more burdensome for the taxpayer to seek relief under an administrative mechanism ${ }^{42}$.

An interesting question also arises from the perspective of the residence State. Should the residence State provide relief (credit under
Article 23) for the $15 \%$ tax levied by the source State (under Article 10(2)) even though from its perspective the item of income is taxable only in its State (under Article 13(5)). The wording of the guiding principle or the PPT rule does not provide any guidance on this issue. The OECD Commentary states that when conflicts of qualification arise from differences in domestic law then the residence State should provide relief from double taxation ${ }^{43}$. However, for qualification conflicts that arise due to differences in treaty interpretation, the OECD is of the view that the residence State should not provide relief automatically but through the mutual agreement procedure ${ }^{44}$. In the author's opinion, the wording of Article 23 does not make a difference between such conflicts. The provision simply states that relief shall be provided for income, which "in accordance with the provisions of this convention" is taxable in the other State. Therefore, as long as the source State taxes an item of income in accordance with the treaty, the residence State shall fulfil its obligations under Article $23^{45}$.

\section{Conclusion}

The purpose of this article was to shed light on a few elements of the PPT rule and guiding principle. The author believes that these rules have their own limitations/issues and are open for subjective interpretations by taxpayers and tax authorities. This will lead to uncertainty and consequently to a significant increase in tax disputes. Thus, taxpayers should have the possibility to resolve such disputes under the mutual agreement procedure or the arbitration clause ${ }^{46}$. Accordingly, the framework suggested by the OECD in the context of BEPS Plan Action 14 on "making dispute resolution mechanisms more effective" will be extremely important. 
1. A commentator has submitted that the meaning of such a phrase can be "narrowed down to those situations where the particular use of a tax treaty i) has the sole intention to avoid the tax of either or both contracting states and ii) defeats fundamental and enduring expectations and policy objectives shared by both states and therefore the purpose of the treaty in a broad sense". See WeEGHEL, Thesis, p. 117. The most common examples of improper use are of taxpayers who engage in treaty shopping or rule shopping schemes. The term treaty shopping represents a situation in which a "person who is not entitled to the benefits of a tax treaty makes use - in the widest meaning of the word - of an individual or legal person in order to obtain those treaty benefits that are not available directly". WEEGHEL, Thesis, p. 119. On the other hand, under a rule shopping exercise, a taxpayer does not search for a favourable tax treaty. A tax treaty already exists and the person who is entitled to a tax treaty employs that treaty in the most favourable manner. Under such a scheme a taxpayer prefers to engineer a transaction is such a way that a particular distributive rule of the tax treaty applies rather than another one. JIMENEZ, Anti Abuse - I, p. 543.

2. 2003/2014 OECD Comm. Art. 1, Para. 9.1.

3. 2003/2014 OECD Comm. Art. 1, Para. 22.1.

4. 2003/2014 OECD Comm. Art. 1, Para. 9.2.

5. 2003/2014 OECD Comm. Art. 1, Para. 7.

6. 2003/2014 OECD Comm. Art. 1, Para. 9.3.

7. 2003/2014 OECD Comm. Art. 1, Para. 9.4.

8. 2003/2014 OECD Comm. Art. 1, Para. 9.5.

9. 2013 OECD, Addressing BEPS.

10. 2013 OECD, BEPS Action Plan, pp. 18-19.

11. 2014 OECD, Discussion Draft on Treaty Abuse.

12. 2014 OECD, Report on Treaty Abuse.

13. Ibid, Para 5.

14. Ibid, Para 11.

15. Ibid, Paras 47-48.

16. Ibid, Para 49

17. Ibid, Para 49 (Commentary in Para 5).

18. Ibid, Para 49 (Commentary in Para 7).

19. Ibid, Para 49 (Commentary in Para 8).

20. Ibid, Para 49 (Commentary in Para 9).

21. Ibid, Para 49 (Commentary in Para 10).

22. Ibid, Para 49 (Commentary in Paras 11-12).

23. Ibid, Para 52. The clause reads as follows "This Convention shall not affect the taxation, by a Contracting State, of its residents except with respect to the benefits granted under paragraph 3 of Article 7, paragraph 2 of Article 9 and Articles 19, 20, 23, 24 and 25 and 28".

24. Ibid, Paras 54-57.

25 The 2003/2014 OECD Commentary provides that this principle applies to domestic statutory GAAR's and domestic judicial doctrines whereas the 2014 TTA report provides that this principle applies only to domestic statutory GAAR's (also TAAR's) and not to domestic judicial doctrines. In the author's opinion, the effect of applying domestic statutory GAAR's or judicial doctrines is quite similar. So why shouldn't a judicial doctrine be applicable "having regard" to the OECD's guiding principle/PPT rule?

26. De Broe/Luts, BEPS, p. 133; LANG, PPT rule, p. 659

27. The OECD Commentary provides that "existing conventions should, as far as possible, be interpreted in the spirit of the revised Commentaries". See 2014 OECD Comm. Introduction, Para. 33. Nevertheless, the OECD seems to provide a limit to this approach by differentiating between commentaries which substantially modify previous versions of the commentary i.e. they lead to a "contrario" interpretation and commentaries that clarify previous versions of the Commentary. For the former, the OECD's view is that such commentary should be disregarded whereas for the latter, the OECD's view is that such Commentary should be considered to be relevant in the tax treaty interpretation process. See 2014 OECD Comm. Introduction, Para. 36. In the author's opinion, the guiding principle was never discussed before the 2003 OECD Commentary. Thus, these changes should not be considered to be relevant when interpreting tax treaties concluded between OECD Member States before 2003, as they are not mere clarifications.

28. 2014 OECD, Report on Treaty Abuse, Para 17 (Commentary in Para 12).

29. 2011 UN Comm. Article 1, Para. 36.

30. De Broe, Thesis, pp. 319-320; Arnold/Weeghel, Abuse, pp. 93-95; Perez/Baez, 2003 changes, p. 153 ; Jimenez, 2003 changes, p. 19.

31. A commentator convincingly demonstates that "the main purpose" test should be used. De BroE, Thesis, pp. 319-325.

32. See ECJ decision, C-255/02, Feb 21, 2006.

33. For instance, see the EU Commissions recommendation on aggressive tax planning dated 6-12-2012 with respect to the general anti abuse rule. Also see LANG, PPT rule, p. 659.

34. Arnold/Weeghel, Abuse, p. 93; Perez/Baez, 2003 changes, p. 153.

35. De Broe, Thesis, p. 344.

36. De Broe, Thesis, pp. 344-355.

37. De Broe, Thesis, p. 319; De Broe/Luts, BePS, p. 132. 


\section{OECD}

38. De Broe/Luts, BEPS, p. 132; LANG, PPT rule, p. 659.

39. De Broe/Luts, BEPS, p. 132; LANG, PPT rule, p. 660.

40. 2014 OECD, Follow up work on BEPS Action 6 : Preventing Treaty Abuse, pp. 10-11.

41. 2014 OECD, Follow up work on BEPS Action 6 : Preventing Treaty Abuse, p. 11.

42. LANG, PPT rule, p. 662.

43. 2003/2014 OECD Comm. Art. 23, Para. 32.1-32.4.

44. 2003/2014 OECD Comm. Art. 23, Para. 32.5.

45. LANG, PPT rule, p. 662.

46. Some OECD countries beleive that the application of the PPT rule is not an issue suitable for the arbitration mechanism of Para 5 of Article 25 of the OECD Model. See 2014 OECD, Follow up work on BEPS Action 6 : Preventing Treaty Abuse, p. 11. 